\title{
Damned if you don't
}

ほ

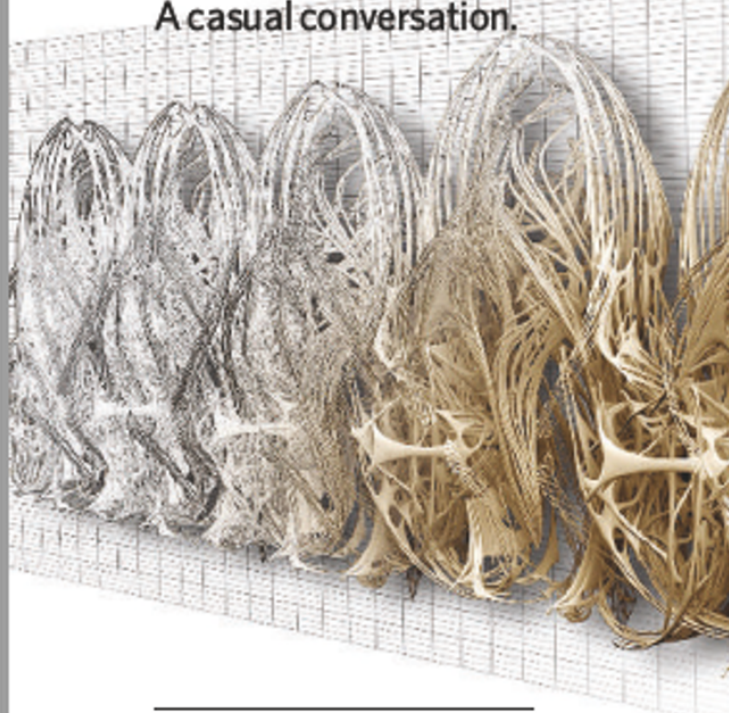

Lucy Bergman

I met a guy with a claw. Don't get me wrong - I have nothing against claws, and it wasn't the first one I'd encountered. It's just that he kept talking about it and waving it around. Boarding for the airship was delayed, as usual, so I didn't mind the chat.

He challenged me to guess his age. I gazed at his face, which looked vaguely familiar. The skin - the non-bearded part that I could see - was smooth. Even smoother than mine, which benefits from hours spent every week inside an antioxidation rejuvenating chamber. And judging by his, he looked younger than me, I had to admit. But his speech and his expression had the gravity of a much older person. I threw him my puzzled look.

"It's artificially grown, my skin," he told me. ${ }^{\alpha}$ I designed it to be extra thick, for firmness and elasticity. It has natural UV filters and I don't even get the odd blemish.

I was awestruck. I'd read about him.

"Are you Stephen Pflaumbaum?" I asked, mentally pinching myself.

Henodded, and held up the claw for my perusal.

"I've had a lifelong passion to make myself a new hand. The skin and soft tissue part turned out to be easy, but I'm still struggling with the individual bones. I can grow acres of bone, but the hand is very complicated and I will only settle for a perfect replica." Smiling slyly, he added: "And I've been distracted recently by the construction of the dam."

The dam he so casually dropped into conversation is the most ambitious architectural marvel of the twenty-first century, the MedDam at Gibraltar. It is made almost exclusively of living bone, the only material that grows and strengthens under stress. In the Netherlands they reinforced their dykes with Buckywall", made of carbon nanotubes, but they failed catastrophically two years ago after the most powerful storm surge for a decade. And now the capital city is Maastricht.

Buckywall $^{\text {" h }}$ had also bid for the MedDam contract but in the end the Mediterranean Council charged with the preservation of the coastline decided to go with Pflaumbaum's plans. His structures are aesthetically appealing as well as being strong and flexible. And once the scaffolding is in place, the high-density bone tissue grows quickly. He'd made a striking demonstration by regrowing one section of the Great Wall in three weeks. Its smooth ivory curve has become a tourist attraction.

A synthetic voice interrupted my thoughts.

${ }^{\alpha}$ We are sorry to announce that boarding will be delayed by a further $20 \mathrm{~min}$ utes. This is due to the late arrival of the incoming airship. We apologize for any inconvenience caused."

I said to Pflaumbaum: ${ }^{\alpha}$ That is exactly the same excuse I hear everyday during my commute! Except it's a ferry."

"Where do you work?" he asked.

"London," I replied. “I'm part of the team redesigning the canal system. In fact, that's why I'm going to Venice. And of course I'd love to visit the old city if I have time. I qualified last month.

At this he brightened, saying, 'I'm going to Venice myself. I used to love it as a child. One time I nearly fell into the water after turning a corner because it was so dark. Luckily my mother grabbed me and held me back, but she nearly ripped out my arm. How I cried and cried until she bought me some gelato. Actually, I didn't even need that as an excuse to get ice cream in those days. I only had to look down at my hand dejectedly and my mother would start pouring out her sympathy. What a horror I was. Plenty of kids had malformed bits then. Now it's all sorted out before birth."

His eyes glanced inadvertently at my right hand. I wanted to withdraw it into my sleeve but refrained. He must have realized because he changed the subject.

"I think we're about to board, ${ }^{\text {" he said, }}$ nodding at the three gates. Indeed, a crowd had gathered by each door, despite knowing full well that seating is by sections and floors. Did they think we would leave without them?

I turned to Pflaumbaum. "It was a pleasure to meet you. I should like to see your dam one day. I'll have an ice cream in your honour."

He smiled. "Enjoy your trip. You really must visit Old Venice. The light down there can be extraordinary. The water is very clear and last time I followed a school of fish through the ducal palace."

Then leaning in, he added: "You know, I'm going to a conference to discuss whether or not we should pump out some water from the Mediterranean, now that the dam is nearing completion. This might be your last chance to dive in San Marca"

With a wink he went to join the hordes. Lucy Bergman lives in Cambridge, UK, and believes the pen is mightier than the pen. 